\title{
Yellow fever in west Africa: a retrospective glance
}

\author{
J S Porterfield
}

\section{Barnstaple, Devon EX32 7NH}

J S Porterfield, MD, formerly reader in bacteriology, Sir William Dunn School of Pathology, University of Oxford

BrMed f 1989;299:1555-7

Hideyo Noguchi dissecting a rhesus monkey in Accra in 1927. fH Bauer is to his right with A F Mahaffy (in bow tie) behind him
In 1986 over 5000 people died of yellow fever in eastern Nigeria'; in 1987 there were over 400 deaths from yellow fever in western Nigeria and over 1500 deaths were estimated to have occurred in northern Nigeria. ${ }^{2}$ These figures are stark reminders that despite the availability of $17 \mathrm{D}$ vaccine ${ }^{3}$ arguably the best of all viral vaccines, yellow fever virus may still kill mercilessly.

From 1953 to 1957 I was seconded by the Medical Research Council to the Virus Research Institute at Yaba, outside Lagos, Nigeria. This laboratory had been established in 1925 by the Rockefeller Foundation as the West Africa Yellow Fever Laboratory, and it was here that yellow fever virus was first isolated. ${ }^{4}$ During my time in west Africa I saw cases of yellow fever in eastern Nigeria and in the Gold Coast (Ghana) and isolated the virus several times. Containment facilities in Yaba were virtually non-existent, indeed, in the words of the director, $\mathrm{F} N$ Macnamara, the laboratory was "knee deep in viruses," but as all the staff had been vaccinated and were shown to be immune to yellow fever virus we had no ill effects. Our predecessors were less fortunate; Adrian Stokes, Hideyo Noguchi, Edward Haynes, and William A Young all died in west Africa from laboratory acquired yellow fever, and laboratories elsewhere had similar catastrophes.

After leaving Nigeria I worked for three months with Max Theiler in the Rockefeller Foundation Virus Laboratories in New York, through whom I met Cornelius B Philip, one of the staff of the foundation, who had had a non-fatal infection with yellow fever in Lagos during those pioneering days. Subsequently I visited Cuba, where history in yellow fever was made even earlier, and Japan, where I visited the Hideyo Noguchi Museum in Tokyo and saw the Noguchi statue, which stands in a woodland park outside Osaka.

The early history of yellow fever and the major role played by the Rockefeller Foundation have been described in detail by Strode, ${ }^{5}$ and there are other

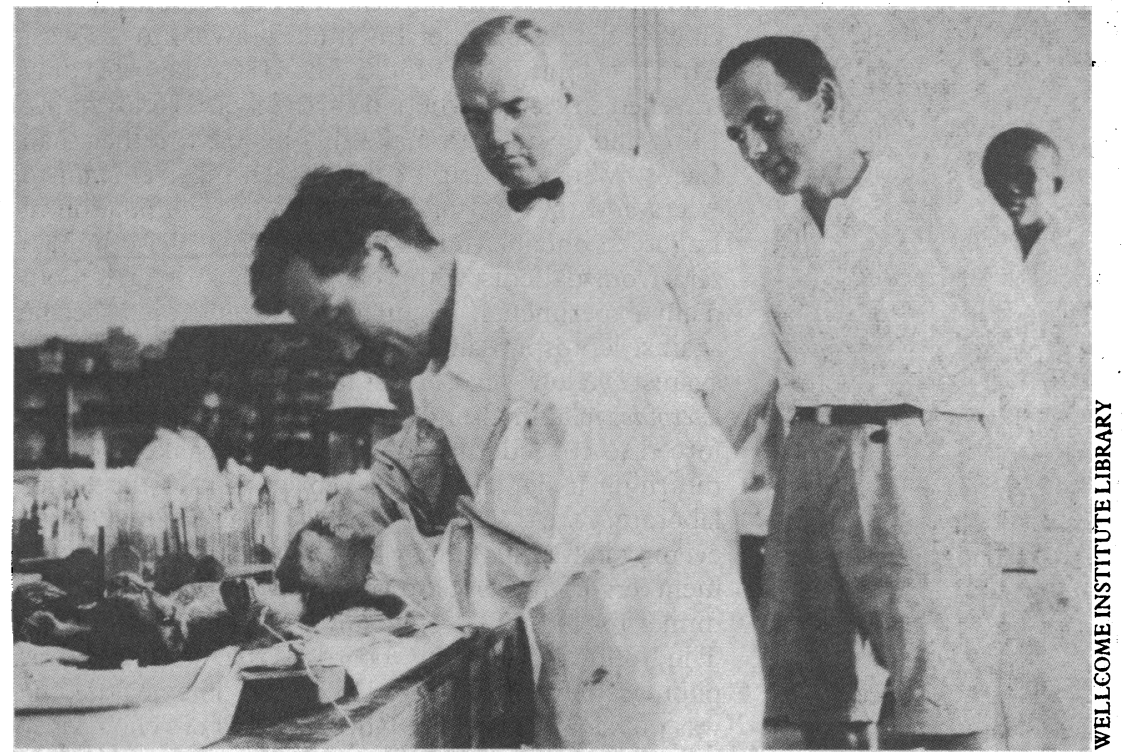

historical accounts. ${ }^{6}$ To a generation constrained by health and safety legislation and by ethical committees the following brief account may be of some interest.

Yellow fever almost certainly originated in Africa, and the disease was probably introduced into the Americas around the time of Christopher Columbus by sailing ships which had visited west Africa. Major epidemics occurred in the Caribbean, in Central and South America, and later in North America, which had periodic outbreaks from 1693 to 1905 . Philadelphia experienced a disastrous epidemic in 1793, and New York, Baltimore, and Boston were all affected early in the nineteenth century. ${ }^{7}$ Europe was also affected, there being 60000 deaths in Madrid in $1800^{8}$ and 17 in Swansea in 1865 after a barque from Cuba introduced the infection. ${ }^{910}$ Yellow fever was endemic in Cuba from 1649 onwards, and during the Spanish-American war there were over 1500 cases and 231 deaths in the United States army in Cuba. The cause and mode of transmission of the disease remained unknown until this century. In 1900 the United States army appointed a yellow fever commission headed by Major Walter Reed to work on the problem in Cuba. R'eed's life is vividly portrayed in a recent biography, ${ }^{11}$ which gives due credit to the roles of his collaborators Agramonte, Carroll, and Lazear.

In 1881 Dr Carlos J Finlay, a general practitioner in Havana of Franco-Scottish parentage, presented evidence that yellow fever was spread by a specific mosquito, now known as Aedes aegypti, but these claims were rejected by the scientific community and by Reed. Lazear, however, was persuaded by Finlay's case and with his help set up a colony of mosquitoes, which he used to carry out transmission studies on human volunteers (there were no ethical committees in those days). Initial experiments proved to be negative, but in a second trial Carroll and another American volunteer both developed severe yellow fever. A few days later Lazear contracted the disease and died after a short illness. He had kept meticulous notes of his experiments, and after his death Reed decided that further experiments on transmission were justified. In a remote centre named Camp Lazear 12 volunteers were exposed to the bites of further infected mosquitoes. These and subsequent experiments proved conclusively that yellow fever was due to a filterable agent that is, a virus; that the virus was present in the blood of infected patients during the first three days of the disease; and that $A$ aegypti may transmit the disease by biting, provided an interval of 12 days was permitted after an infective feed. ${ }^{12}$ The information allowed Major William C Gorgas to mount control against mosquitoes that eradicated yellow fever from Havana, and later he was responsible for controlling the disease in Panama, allowing de Lesseps to complete the building of the Panama Canal. Ironically, Reed did not live to see these successes; he died in 1902 from peritonitis after appendicitis. Some 50 years later these dramatic events were commemorated at Parque Lazear, outside Havana, where plaques naming each of the United States army volunteers were erected a few metres from the simple wooden hut in which Finlay kept his infected mosquitoes.

Although the evidence of the Reed commission 
clearly incriminated a virus, another quarter of a century was to elapse before it was isolated. Meanwhile, in 1916, the Rockefeller Foundation set up its first yellow fever commission under Gorgas, now a general, with the eradication of $A$ aegypti as one its objectives. In 1918 the commission investigated an epidemic of yellow fever in Ecuador, and one of its members, the Japanese scientist Hideyo Noguchi, who was a staff member of the Rockefeller Institute in New York, claimed that the causal agent was not a virus but a leptospire, which he named Leptospira icteroides. ${ }^{1314}$ He prepared a vaccine against this organism, stating that this gave protection against yellow fever for six months. Noguchi was a distinguished bacteriologist, having earlier isolated the bacterium now known as Leptospira icterohaemorrhagiae (Noguchi) from Norway rats, ${ }^{15}$ which had been shown to be the cause of Weil's disease. Hindsight and the fact that he also claimed to have cultivated the spirochaete of syphilis and the causal agents of poliomyelitis and rabies make it difficult to understand how Noguchi's claims became so widely accepted, but they unquestionably affected the whole of the yellow fever programme in the Americas and in Africa. A recent biography of Noguchi gives many insights into this charismatic man. ${ }^{16}$

In French west Africa the medical authorities reported that "Noguchi's vaccine and serum was used with advantage" in controlling an epidemic that spread into French territory from Nigeria and the Gold Coast. ${ }^{17}$ In Nigeria staff at the laboratories of the Rockefeller Foundation's yellow fever commission spent from 1925 to 1927 investigating Noguchi's claim, but were unable to confirm the presence of leptospira in any patients with yellow fever. Their tests were fairly simple as Noguchi's organism produced sickness or death in guinea pigs and could be identified microscopically. If Noguchi was wrong and yellow fever was indeed a viral infection there was an urgent need to find a susceptible animal if the use of human volunteers was to be avoided. Various animal species, including African monkeys, proved not to be susceptible, and the director of the commission, Henry $\mathrm{E}$ Beeukes, decided to try Asiatic monkeys. These were

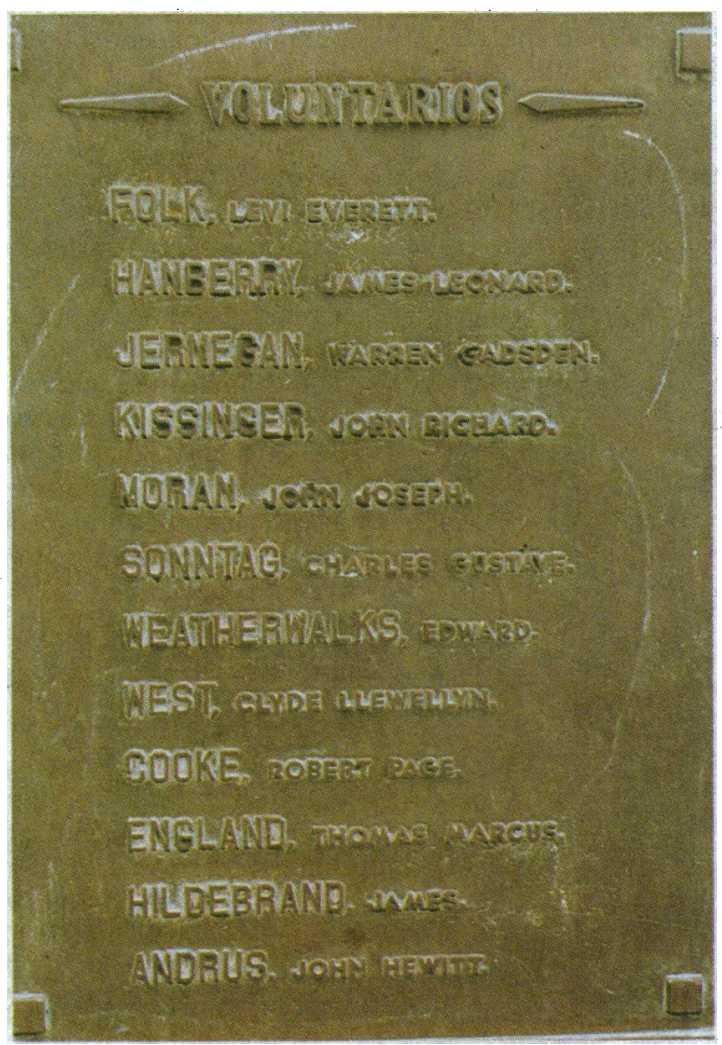

obtained from Europe and shipped to Accra, where they arrived on 25 May 1927 accompanied by Beeukes and Stokes (on leave of absence from his post as Sir William Dunn professor of pathology at Guy's Hospital). Two other members of the Rockefeller team, A F Mahaffy and J H Bauer were already in Accra investigating a small outbreak of yellow fever in the Gold Coast, during which Mahaffy collected blood from a 27 year old African, named Asibi, who had a mild attack of yellow fever in a village about $160 \mathrm{~km}$ from Accra and inoculated it into a Macacus rhesus monkey. On the fourth day the monkey was moribund; a second rhesus monkey was inoculated with its blood and was immediately transported by Bauer to the laboratory in Lagos, an overnight sea voyage. Stokes travelled to Lagos shortly after this, and he, with Bauer and N Paul Hudson, who had just arrived from the United States, began a series of passages in further rhesus monkeys and performed transmission studies with $A$ aegypti. Stokes established that rhesus monkeys were not susceptible to Noguchi's leptospira and that antileptospiral antiserum failed to protect monkeys against the Asibi virus. These experiments confirmed the earlier findings of the Reed commission and established beyond reasonable doubt that the true causal agent of yellow fever had been isolated and that it was a virus and not a leptospire. ${ }^{4}$ The only missing link was evidence that the virus could produce yellow fever in humans, and that followed very quickly through the death on 19 September 1927 of Adrian Stokes.

In a tribute to Stokes published much later Hudson noted that Stokes had suggested that the final link in the chain should be completed through the use of human volunteers, but that the other members of the commission and the local medical authorities had opposed this as being too hazardous and also unnecessary as the evidence had been advanced. ${ }^{18}$ Although the route of infection cannot be stated with certainty, Hudson believed that Stokes became infected through handling infected monkey tissue without wearing gloves. Stokes was not concerned with any transmission experiments with mosquitoes, thereby excluding that route of infection. Stokes had insisted that mosquitoes be fed on his leg, and these later transmitted the disease to monkeys. The chain was now complete.

Stokes died from infection with the Asibi strain of the virus. A decade later this virulent strain was attenuated by multiple passages in minced mouse embryos, then in chick embryo cells in culture, and finally in embryonated eggs $^{3}$ to give the $17 \mathrm{D}$ vaccine, which remains in use today.

Noguchi questioned the validity of the virological studies in west Africa and asked Dr Simon Flexner, his chief at the Rockefeller Institute, if a visit to the west African laboratories could be arranged. He duly travelled to Accra, where he arrived on 17 November 1927, and decided to make this his base, rather than Lagos. With the help of the British medical team in Accra and the staff of the Rockefeller Foundation in Lagos he obtained monkeys and acute phase human sera from patients with yellow fever and carried out many experiments. Noguchi had received his vaccine against leptospira and believed that he was protected against yellow fever. He failed to find Leptospira icteroides in animals infected with yellow fever and was forced to concede that he had been mistaken. Before returning to Japan he paid a brief visit to the Lagos laboratory, arriving there on 10 May 1928. On the evening before his ship was due to sail from Lagos the members of the laboratory staff organised a farewell dinner for him but Noguchi was too unwell to attend. The following day he boarded the ship and was photographed on deck by Dr Philip. The next day he was put ashore at Accra, where he died of yellow fever 


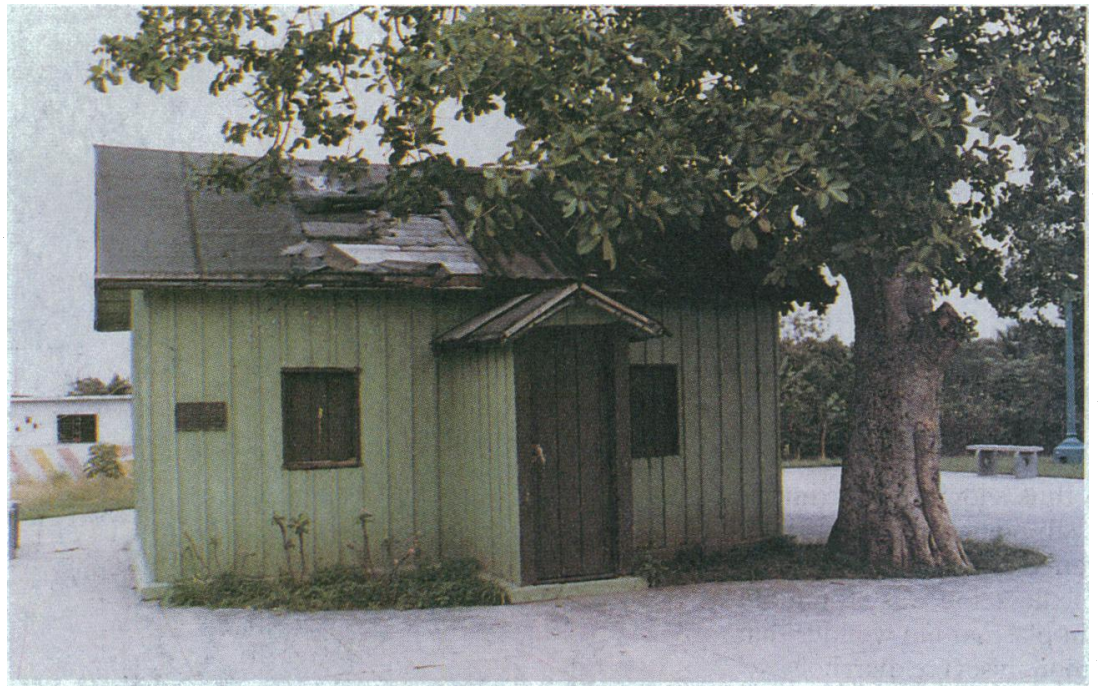

Finlay's laboratory, Parque Lazear, Havana on 21 May. W A Young, a British pathologist in Accra who had been working with Noguchi, also died of yellow fever on 29 May.

Several writers have suggested that Noguchi, having accepted that he had been mistaken, deliberately infected himself with yellow fever as a form of scientific hari kari. Philip dismisses this suggestion, believing that a laboratory accident was much more likely. On his way to Lagos Philip left the ship for a few hours in Accra to visit the Medical Research Institute but found Noguchi asleep, having worked all night, as he frequently did to avoid other members of the laboratory. Philip had intended to take some infected mosquitoes from Accra to Lagos but on inspecting the cages found so many holes through which mosquitoes might escape that he decided not to take any. Plesset concurs with the view that conditions in Noguchi's laboratory were chaotic. ${ }^{16}$ Philip was aware of the hazard of being bitten by an infected mosquito, and when this happened to him in his own mosquito house in Lagos he was immediately injected with convalescent serum preserved with tricresol, which may well have saved his life. Haynes who came out to Lagos to relieve Philip, was less fortunate and died of yellow fever, almost certainly acquired in the same manner.
Although in 1902 Gorgas looked forward to the disappearance of yellow fever after the control of $A$ aegypti, the emergence of jungle yellow fever with an entirely different vector species dashed his hopes. There is no prospect that yellow fever can be eradicated in the same way as smallpox. The control of aedes is still important in limiting yellow fever in urban areas, but vaccination provides the best safeguard. The people who died in the yellow fever epidemics in Nigeria in 1986 and 1987 were unvaccinated, apart from one peron who had received $17 \mathrm{D}$ vaccine only five days previously, too short an interval to be protective. Asibi's yellow fever was mild, and he made a complete recovery. In the 1950 s he was traced by the medical authorities in the Gold Coast and was given a pension by the Colonial Office to commemorate his part in the epic history of the control of yellow fever. Sadly, that control is all too commonly absent in parts of the world where it is most needed.

I thank Dr C B Philip, whose comments and letters are largely responsible for the writing of this article.

1 DeCock KM, Monath TP, Nasidi A, et al. Epidemic yellow fever in Eastern Nigeria, 1986. Lancet 1988;i:630-3.

2 Nasidi A, Monath TP, DeCock KM, et al. Urban yellow fever epidemic in Western Nigeria, 1987. Trans $R$ Soc Trop Med Hyg 1989;83:401-6.

3 Theiler $M$, Smith $\mathrm{HH}$. Use of yellow fever virus modified by in vitro cultivation for human immunization. $\mathcal{F}$ Exp Med 1937;65:787-800.

4 Stokes A, Bauer JH, Hudson NP. Experimental transmission of yellow fever to laboratory animals. Am J Trop Med 1928;8:103-64.

5 Strode GK. Yellow fever. New York: McGraw Hill, 1951:1-710.

6 Carter HR. Yellow fever, an epidemiological and historical study of its place of origin. Baltimore: Williams and Wilkins, 1931.

7 Blake JB. Symposium on American contributions to the history of tropical medicine. Bull NY Acad Sci 1968;44:621-754.

8 Theiler M. Yellow fever. In: Rivers TM, ed. Viral and ricketsial infections of man. 2nd ed. Philadelphia: Lippincott, 1952:531-51.

9 Smith CEG, Gibson CE. Yellow fever in South Wales, 1865. Med Hist 1986;30:322-40.

10 Meers PD. Yellow fever in Swansea, 1865. J Hygiene 1986;97:185-91.

11 Bean WB. Walter Reed: a biography. Charlottesville: University Press of Virginia, 1982

12 Reed W, Carroll J. Etiology of yellow fever: supplemental note. American Medicine 1902;3:301-5.

13 Noguchi H. Etiology of yellow fever; transmission experiments on yellow fever. $\mathcal{E}$ Exp Med 1919;29:565-84.

14 Noguchi H. Yellow fever research, 1918-1924: summary Leptospira icteroides. f Trop Med 1925;28:185-93.

15 Noguchi H. Spirochaeta icterohaemorrhagiae in American wild rats and its relation to the Japanese and European strains. $\mathcal{J}$ Exp Med 1917;25:755-63.

16 Plesset IR. Noguchi and his patrons. Cranbury, New Jersey: Associated University Presses, 1980

17 Anonymous. Report from Paris. Lancet 1927;i:1265.

18 Hudson NP. Adrian Stokes and yellow fever research: a tribute. Trans $R$ So Trop Med Hyg 1966;60:170-4.

\section{Bramhope, Leeds LS16 9JD \\ Frank M Parsons, FRCP retired consultant in renal medicine \\ Dr Parsons, formerly consultant renal physician and senior lecturer in medicine at the University of Leeds until his retirement in 1983, died on 17 August (Obituary, 2 December, p 1396).}

Br Med f 1989;299:1557-60

\title{
Origins of haemodialysis in the United Kingdom
}

\author{
Frank M Parsons
}

I qualified in medicine in 1943 at the University of Leeds, having obtained a BSc with honours in physiology on the way. After working for three years as a house surgeon and demonstrator in physiology I took the primary FRCS examination and joined the Royal Army Medical Corps as a graded surgeon. I was demobbed in the summer of 1949, a year after the start of the NHS. Having learnt the new terminology of the hospital medical staff and noted an administrator at every corner, I was appointed registrar to $\mathrm{Mr}$ Pyrah - a lucky choice as he was one of the foremost surgeons in Leeds and had an interest in urology.

The next sumimer after I returned from holiday a serious outbreak of infection caused by Pseudomonas aeruginosa occurred in the prostate ward. An open system of bladder drainage was then in use and the pathologist, Dr Goldie, soon traced the source to large tanks filled with Dettol in which the urinals were placed for "sterilisation." I changed this to a closed system of bladder drainage which was fully autoclavable, including the drainage bottles. The result was dramatic: urine remained sterile for weeks even with continued bladder drainage. In the 1930s and early 'forties prostatectomy had a mortality of $70 \%$ because the new closed methods of prostatectomy with a mortality of less than $10 \%$ were not commonly used. Patients with prostate problems therefore tended to keep their prostates as long as possible, eventually being admitted with urinary retention that required drainage of the bladder. My development of a closed drainage system encouraged Mr Pyrah to build up a research department, and beforè long I was appointed research fellow in urology at the University of Leeds by the vice chancellor, Mr Pyrah, the professor of surgery, and the registrar of the university - the "top brass" of the university appointing the lowest of the 